\title{
FLEXIBILITA NA TRHU PRÁCE
}

\section{Ivana Brožíková}

\section{Klíčová slova:}

trh práce, míra nezaměstnanosti, pracovní doba, zkrácená pracovní doba, flexibilní formy zaměstnávání, pozitivní flexibilita, negativní flexibilita, podzaměstnanost, marginalizace, absolventi škol.

\section{Key words:}

labour market, the rate of unemployment, working hours, shorter working hours, flexible forms of employment, flexibility, positive, negative flexibility, underemployment, marginalization, school graduates.

\begin{abstract}
Abstrakt:
Článek se zabývá využíváním flexibilních forem zaměstnávání, které mají za určitých podmínek pozitivní vliv na trh práce. V zemích Evropské unie je tato forma zaměstnávání v porovnání s pracovním trhem v České republice mnohem více využívána. Porovnává údaje o stavu zaměstnaných osob na zkrácenou pracovní dobu v zemích Evropské unie a v České republice $\mathrm{s}$ ohledem na úroveň míry nezaměstnanosti $\mathrm{v}$ jednotlivých zemích. Flexibilita se projevuje na trhu práce svou pozitivní i negativní formou, zejména podzaměstnaností a marginalizací některých skupin obyvatelstva. Rozhodování nezaměstnaných o možnosti pracovat na zkrácenou pracovní dobu jsem si ověřila výzkumem, jehož závěry v článku publikuji. Poslední kapitola článku se zabývá využitím flexibilních forem zaměstnávání v podmínkách trhu práce v České republice.
\end{abstract}

\begin{abstract}
:
The article deals with using flexible forms of employment which, under certain circumstances have a positive impact on the labour market. In European Union countries, this form of employment in comparison with the labour market in the Czech Republic is much more often used. The data are compared on the status of employed part-time jobs persons in the European Union and the Czech Republic with regard to the level of unemployment in each country. Flexibility is reflected in the labour market and has a positive or negative way, especially underemployment and marginalization of certain population groups. Decisions of the unemployed about the possibility to work on part time I have checked by the research, the conclusions of that are published in the article. The last chapter deals with the article, using flexible forms of employment in labour market conditions in the Czech Republic.
\end{abstract}

\section{Úvod}

Trh práce je specifickým trhem výrobního faktoru práce, jehož nerovnováha vzniká důsledkem nesouladu nabídky práce a poptávky po práci. Výrazným aspektem ovlivňujícím poptávku po práci je nepružnost mzdových sazeb. Výsledkem existence mnoha dalších faktorů působících na trh práce je nerovnováha pracovního trhu projevující se vysokou mírou nezaměstnanosti.

Mezi vlivné faktory způsobující nesoulad mezi nabídkou práce a poptávkou po práci patří úroveň nastavených podpor v nezaměstnanosti, které ne vždy působí motivačně při hledání pracovního místa, zvyšující se produktivita práce $\mathrm{v}$ podnicích $\mathrm{v}$ důsledku vývoje $\mathrm{v}$ oblasti techniky a informačních technologií a motivace lidí k práci a k rozvoji jejich předpokladů k lepšímu uplatnění se na trhu práce. „Ztráty, ke kterým dochází v období vysoké 
nezaměstnanosti, jsou největším doloženým mrháním zdrojů v soudobé ekonomice.“ (Samuelson, 1991, s. 285).

Ve svém článku se zamýšlím nad dalším a v poslední době často diskutovaným jevem, který by mohl mít za určitých podmínek pozitivní vliv na trh práce. Jde o flexibilní formy zaměstnávání, jejichž obecnost a konkretizace je součástí dalšího textu. Cílem mé práce je ověřování hypotézy o pozitivním vlivu využivání flexibilních forem zaměstnávání, zejména práce na zkrácenou pracovní dobu, na růst zaměstnanosti. Přestože v rámci Evropské unie, zejména v jejich západních zemích, není výše uvedená forma zaměstnávání novou záležitostí, v České republice je využivána zatím velmi opatrně. Komparace údajů o stavu zaměstnaných osob na zkrácenou pracovní dobu v zemích Evropské unie a v České republice s ohledem na úroveň míry nezaměstnanosti v jednotlivých zemích má velmi zajímavé výsledky. Flexibilní formy zaměstnávání jsou specifické svými výhodami i nevýhodami plynoucími z jejich realizace na trhu práce. Pro určité kategorie uchazečů o zaměstnání, mezi které bych zařadila absolventy škol patřící do kategorie obtížně zaměstnavatelných s ohledem na získání potřebných pracovních návyků a praktických zkušeností pro rozvoj svých kompetencí důležitých k lepšímu uplatnění se na trhu práce, se jeví zcela vhodné a vyhovující.

\section{Flexibilní formy zaměstnávání}

„Pracovní trh směřuje ke stále větší flexibilitě - to znamená na jedné straně oslabení modelu celoživotního zaměstnání na smlouvu na dobu neurčitou, s pevně daným začátkem a koncem pracovní doby, což přináší nové možnosti kombinace pracovního a soukromého života a rozšiřuje možnosti volby životního stylu. Na druhé straně jsme svědky nárůstu flexibility vynucené zaměstnavatelem vyžadující pohotovost zaměstnance v různých denních a nočních hodinách, dlouhou denní přitomnost na pracovišti, či naopak nedobrovolného zkracování úvazku za účelem snížení nákladů pro zaměstnavatele. Průvodním jevem flexibilizace je výrazné snižování jistoty práce.“(Dudová, 2008, s. 11).

Flexibilní forma zaměstnávání je jakýkoliv jiný nestandardní pracovní režim než zákoníkem práce stanovená týdenní pracovní doba, která nesmí překročit čtyřicet hodin týdně. Zaměstnavatel může zaměstnanci zkrátit stanovenou týdenní pracovní dobu bez snížení mzdy, pokud je tato úprava obsažena v kolektivní smlouvě, nebo je upravena vnitřním předpisem. Délku pracovní doby a odměnu za vykonanou práci však může zaměstnavatel zaměstnanci úměrně zkrátit. K nestandardním formám práce v současné době patř́i pružná pracovní doba, zkrácená pracovní doba, job-sharing - sdílení jednoho pracovního místa více osobami, práce $\mathrm{z}$ domova, subcontracting, tj. zaměstnávání zaměstnanců na základě jiné než pracovní smlouvy, např̀. dohody o provedení práce nebo dohody o pracovní činnosti. (Kociánová, 2010).

Využívání pracovníků na částečný úvazek má pro zaměstnavatele určité výhody. Jde o větší možnost uplatnění flexibilní pracovní doby, lepší využití budov a zařízení zavedením další směny, snižují se náklady práce na jednotku výroby způsobené redukcí př́íplatků za přesčasovou práci pro pracovníky na plný úvazek a zvyšuje se produktivita práce způsobená větší pozorností pracovníka při práci během kratší pracovní doby. (Armstrong, 2007, s. 321).

Flexibilitou práce se zabývá teorie segmentovaného trhu, rozdělující trh práce na primární trh a sekundární trh. Primární trh práce je charakteristický stabilitou pracovních míst, možnostmi kariérního růstu a s tím souvisejícími vyššími odměnami za vykonanou práci. Na druhé straně trhu práce pak dochází k menší stabilitě pracovních míst bez možnosti kariérního postupu 
s nižším mzdovým ohodnocením. Na výše uvedenou teorii segmentovaného trhu navazuje teorie flexibilní firmy J. Atkinsona a N. Meagera z 80. let 20. století, která charakterizuje flexibilní firmu jako firmu pružně reagující na požadavky trhu a využívající funkční, numerickou a finanční flexibilitu. (Dudová, 2008). V rámci funkční flexibility, nazývané také interní flexibilitou jsou pracovníci firmy soustavně školeni a rekvalifikováni za účelem jejich schopností realizovat různé pracovní úkoly. Přizpůsobení počtu pracovníků a jejich pracovní doby potřebám firmy zahrnuje numerická neboli externí flexibilita. Finanční flexibilitou je označována přizpůsobivost mzdového ohodnocení za vykonanou práci na aktuálním pracovním trhu. (Dudová, 2008).

Nabídka práce je rostoucí flexibilitou rozdělena na skupinu osob, která dokáže využít nabízených výhod trhu práce a naopak na skupinu lidí, kteří jsou nuceni pracovat za nepřiměřeně nízké odměny za vykonanou práci. Flexibilita práce se tak projevuje svou pozitivní formou tím, že umožňuje pracující osobě lépe kombinovat svůj soukromý život s prací. K negativním formám flexibility zaměstnávání na trhu práce dochází v př́ípadech, $k d y$ je zaměstnanec nucen přizpůsobit se požadavkům zaměstnavatele, které nekorespondují s potřebami kombinace práce a volného času zaměstnance. Negativní flexibilita může způsobit také firmám neprŕznivé důsledky, projevující se poklesem produktivity práce zaměstnanců. Ve firmách začíná docházet k segmentaci zaměstnanců na kmenové zaměstnance, tvořící skupinu kvalifikovaných zaměstnanců s jistotou zaměstnání a ostatní zaměstnance, jejichž práci firmy využívají pouze v př́padech zajištění zvýšené poptávky po práci. (Dudová, 2008).

Důsledkem vývoje trhu práce s výše uvedenými specifiky je marginalizace některých skupin obyvatel, zejména absolventů škol, dlouhodobě nezaměstnaných, matek pečující o děti a osob zdravotně postižených. Podle Brožové (2003) se může projevovat u dlouhodobě nezaměstnaných hystereze na trhu práce, která se projevuje ztrátou smyslu pro povinnost, poklesem získaných odborností, návykem na skutečnost, že člověk nepracuje.

\section{Komparace stavu trhu práce a využívání zkrácené pracovní doby v zemích EU a v $\check{\mathbf{C}} \mathbf{R}$}

Trh práce v České republice, ale také ve všech zemích Evropské unie neměl ve sledovaném období let 2008 až 2010 příznivý vývoj. Nabídka práce ve všech zemích výrazně převyšovala poptávku po práci a výsledkem jejich vzájemného působení byla vysoká míra nezaměstnanosti. Př́činy i důsledky vysoké míry nezaměstnanosti jsou ve všech zemích obdobné, každá země však působí svými opatřeními ke zmírnění negativních dopadů nezaměstnanosti různě. Např́klad některé země dočasně snížily zdravotní pojiššnní, podporovaly podnikání, kompenzovaly mzdy práce na méně hodin, poskytovaly finanční úlevy při přijímání nových pracovníků a hlavně zvyšovaly výdaje na aktivní politiku zaměstnanosti, zejména na rekvalifikaci. Nizozemí využívá již několik let v rámci situace na trhu práce zkrácené pracovní úvazky. Tato země patří k zemím s nejnižší mírou nezaměstnanosti mezi zeměmi Evropské unie.

Pro objektivní porovnání míry nezaměstnanosti jsem zvolila ukazatele zpracované EUROSTATEM na základě primárních dat z LFS ${ }^{1}$ jednotlivých členských států Evropské unie tak, aby zabezpečovaly mezinárodní srovnání mezi jednotlivými členskými státy (Analýza vývoje zaměstnanosti a nezaměstnanosti v roce 2008, 2009, 2010 - př́lohy Další ukazatele trhu práce).

\footnotetext{
${ }^{1}$ Labour Force Survey (výběrové šetření pracovních sil)
} 
V uvedené tabulce uvádím pouze úroveň ukazatelů v těch zemích, které vykazují výrazné rozdíly vzhledem k průměrným hodnotám v Evropské unii.

Tabulka č. 1: Míra nezaměstnanosti a podíl zaměstnaných na zkrácenou pracovní dobu v letech 2008 - 2010 ve vybraných zemích Evropské unie

\begin{tabular}{|c|c|c|c|c|c|c|}
\hline \multirow[b]{2}{*}{ v \% } & \multicolumn{2}{|c|}{2008} & \multicolumn{2}{|c|}{2009} & \multicolumn{2}{|c|}{2010} \\
\hline & MN & $\begin{array}{l}\text { Podíl } \\
\text { ZPD }\end{array}$ & $\mathbf{M N}$ & $\begin{array}{l}\text { Podíl } \\
\text { ZPD }\end{array}$ & $\mathbf{M N}$ & $\begin{array}{l}\text { Podíl } \\
\text { ZPD }\end{array}$ \\
\hline EU 27 & 7,0 & 18,2 & 9,0 & 18,7 & 9,6 & 19,1 \\
\hline Nizozemí & 3,1 & 47,3 & 3,7 & 48,2 & 4,5 & \\
\hline Dánsko & 3,3 & 24,6 & 6,0 & 26,0 & 7,4 & \\
\hline Rakousko & 3,8 & 23,3 & 4,8 & 24,6 & 4,4 & \\
\hline Německo & 7,3 & 25,9 & 7,5 & 26,1 & 6,9 & \\
\hline Česká republika & 4,4 & 4,9 & 6,7 & 5,5 & 7,3 & 5,9 \\
\hline Mad'arsko & 7,8 & 4,6 & 10,0 & 5,5 & 11,2 & \\
\hline Slovensko & 9,5 & 2,7 & 12,0 & 3,6 & 14,4 & \\
\hline Španělsko & 11,3 & 12 & 18,0 & 12,6 & 20,1 & \\
\hline
\end{tabular}

Zdroj: vlastni tvorba ze zdrojů Analýza vývoje zaměstnanosti a nezaměstnanosti v roce 2008, 2009, 2010, príloha - zdroj: $\check{C} S \dot{U}-V \check{S} P S^{2}$

Podíl zaměstnaných na zkrácenou pracovní dobu za rok 2009 je zveřejněn v Analýze vývoje zaměstnanosti a nezaměstnanosti v roce 2009, vydané MPSV ČR, v príloze Další ukazatele trhu práce - srovnání členských států EU pouze za 1. - 3. čtvrtletí. Podíl zaměstnaných na zkrácenou pracovní dobu za rok 2010 nebyl ve výše uvedené statistice zveřejněn. Podle Analýzy vývoje zaměstnanosti a nezaměstnanosti v roce 2010 vydané MPSV ČR pracovalo v České republice v roce 2010 na kratší pracovní dobu 5,9 \% zaměstnaných, v EU 27 v prvním až třetím čtvrtletí roku 2010 pak 19,1 \% zaměstnaných. Podíl zaměstnaných na kratší pracovní dobu v České republice je v rámci Evropské unie považován za extrémně nízký.

Analýzou vybraných ukazatelů zjistíme, že země s vyšším podílem zaměstnaných na zkrácenou pracovní dobu vykazují nižší míru nezaměstnanosti v porovnání s ostatními zeměmi, ve kterých je zkrácená pracovní doba využívána méně. Nejvíce je zkrácená pracovní doba využívána v Nizozemí u 48,2 \% zaměstnaných, v Dánsku u $26 \%$, v Německu je zaměstnáno na zkrácenou pracovní dobu 26,1 \% zaměstnaných a v Rakousku 24,6 \% zaměstnaných. Uvedené země Evropské unie vykazují ve sledovaném období nejnižší míru nezaměstnanosti. Zaměříme-li se na analýzu statistických údajů o počtu zaměstnaných v národním hospodářství na kratší pracovní dobu v České republice uvedené v tabulce č. 2, zjistíme, že počet zaměstnaných na kratší pracovní úvazek se ve sledovaném období zvyšuje. V roce 2008 pracovalo na zkrácenou pracovní dobu celkem 245,3 tisíc osob, v roce 2010 se počet takto zaměstnaných osob zvýšil na 288,6 tisíc, z nichž $71,5 \%$ tvořily ženy. Do kategorie podzaměstnaných jsou zařazeny podle metodiky ILO ${ }^{3}$ všechny osoby, které pracují ve svém hlavním zaměstnání na částečný úvazek nebo méně než 40 hodin týdně, ale přejí si a jsou schopny pracovat vyšší počet hodin. (Analýza vývoje zaměstnanosti a nezaměstnanosti v roce 2010 vydaná MPSV ČR, s. 14).

\footnotetext{
${ }^{2}$ Výběrové šetření pracovních sil (LFS - Labour Force Survey)

${ }^{3}$ Mezinárodní organizace práce
} 
Počet podzaměstnaných osob se ve sledovaném období meziročně zvyšuje. Zajímavým se jeví poměrový ukazatel struktury podzaměstnaných v procentním vyjádření, který se sice každoročně zvyšuje, ale v porovnání s procentem podzaměstnaných mužů i žen nevykazuje výrazné rozdíly, přestože počet zaměstnaných žen na kratší pracovní dobu počet takto zaměstnaných mužů výrazně převyšuje.

Práce na kratší pracovní dobu jako flexibilní forma zaměstnávání je pro velký počet žen vyhovující a přijatelná. Nejpočetněji zastoupenou kategorií osob pracujících na zkrácenou pracovní dobu ve sledovaném období jsou ženy ve věkové skupině 30 - 44 let, které ve statistikách MPSV ČR uvádějí jako nejčastější důvod volby práce na zkrácenou pracovní dobu osobní, rodinné důvody a péči o dítě. Muži pracují na zkrácenou pracovní dobu nejčastěji ze zdravotních důvodů a nejvyšší počet takto zaměstnaných mužů jsou v období let 2008 až 2010 muži starší 60 let.

Mezi nejvíce zastoupená odvětví v České republice z hlediska zaměstnávání na zkrácenou pracovní dobu patři odvětví velkoobchodu a maloobchodu, vzdělávání, a zdravotní a sociální péče.

Tabulka č. 2: Zaměstnaní v NH - zkrácená pracovní doba a podzaměstnanost v ČR

\begin{tabular}{|l|r|r|r|r|r|c|}
\hline \multirow{2}{*}{ Zaměstnaní v NH } & \multicolumn{2}{|c|}{2008} & \multicolumn{2}{c|}{2009} & \multicolumn{2}{c|}{2010} \\
\cline { 2 - 7 } & v tis. & v \% & v tis. & v \% & v tis. & v \% \\
\hline Celkem na kratší úvazek & 245,3 & 100 & 273,1 & 100 & 288,6 & 100 \\
Z toho podzaměstnaní celkem & 37,9 & 15,5 & 54,6 & 20 & 60,4 & 20,9 \\
\hline Muži na kratší pracovní úvazek & 63,7 & 26 & 79,0 & 29 & 82,2 & 28,5 \\
Z toho podzaměstnaní celkem & 9,4 & 14,8 & 17,5 & 22,2 & 18,8 & 22,9 \\
\hline Ženy na kratší pracovní úvazek & 181,6 & 74 & 194,1 & 71 & 206,4 & 71,5 \\
Z toho podzaměstnaní celkem & 28,5 & 15,7 & 37,1 & 19 & 41,6 & 20,2 \\
\hline
\end{tabular}

Zdroj: vlastní tvorba ze zdrojů Analýza vývoje zaměstnanosti a nezaměstnanosti v roce 2008,

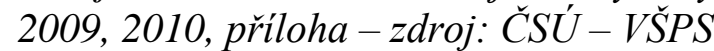

Nerovnováha na trhu práce je problémem všech členských zemí Evropské unie a v souvislosti $\mathrm{s}$ jeho řešením se o flexibilitě na trhu práce často diskutuje.

„Propojení flexibility a jistoty v tzv. konceptu „flexicurity“ je jedním z cílů Evropské unie. Uplatňování tohoto principu by mělo vést k podpoře vzestupné pracovní mobility zaměstnanců, plynulému pohybu pracovníků mezi různými zaměstnáními během života a zároveň i k jejich lepší zaměstnavatelnosti, a to v každém období života. Na druhé straně by mělo dojít k rozvoji flexibilní organizace práce, která umožní lepší slad'ování pracovního a soukromého života.“(Dudová, 2008, s. 17).

\section{Interpretace závěrů výzkumu o možnostech zaměstnávání uchazečů o zaměstnání na zkrácenou pracovní dobu}

$\mathrm{V}$ rámci výzkumu $\mathrm{v}$ oblasti podpory zaměstnanosti jsem zjištovala mezi uchazeči o zaměstnání jejich zájem o zaměstnávání na zkrácenou pracovní dobu. Pro získávání informací jsem zvolila empirickou metodu dotazníkového šetření. Respondenty šetření byli uchazeči o zaměstnání, kteří se účastnili rekvalifikačních kurzů na Obchodní akademii v Orlové ve věkovém rozpětí 20 až 60 let, z nichž $15 \%$ bylo vysokoškolsky vzdělaných a $85 \%$ respondenti̊ mělo vzdělání ukončeno maturitní zkouškou. Z celkového počtu 50 respondentů bylo osloveno $8 \%$ mužů a $92 \%$ žen. Cílem výzkumu by zjištování, zda by nezaměstnaní lidé, pobírající podporu v nezaměstnanosti, upřednostnili možnost pracovat na zkrácenou pracovní dobu před realitou nezaměstnanosti. V rámci klasifikace údajů jsem 
odpovědi respondentů rozčlenila do čtyř kategorií podle kriteria věkové struktury z důvodu mého předpokladu o rozdílnosti názorů různých věkových skupin obyvatel na stanovený jev. Výsledky výzkumu uvádím v tabulce č. 3. Nejpočetnější kategorií uchazečů, pro které by byla práce na zkrácenou pracovní dobu přijatelná a vyhovující, tvořily uchazečky o zaměstnání ve věku od 30 do 49 let. Výsledek statistického zkoumání je shodný s publikací statistiky MPSV ČR, kterou se zabývám v předcházející kapitole.

Tabulka č. 3: Zájem nezaměstnaných o zaměstnání na zkrácenou pracovní dobu z hlediska věku uchazečů o zaměstnání

\begin{tabular}{|l|c|c|c|c|}
\hline Věk uchazečů & $\mathbf{2 0}-\mathbf{2 9}$ let & $\mathbf{3 0}-\mathbf{3 9}$ let & $\mathbf{4 0}-\mathbf{4 9}$ let & $\mathbf{5 0}$-59 let \\
\hline Preference práce na ZPD & $50 \%$ & $55 \%$ & $57 \%$ & $40 \%$ \\
\hline
\end{tabular}

Zdroj: dotaznikové šetření v rekvalifikačních kurzech

Další část výzkumu byla zaměřena na zjištění závislosti mezi výši vyplacených podpor v nezaměstnanosti a zájmem o práci na zkrácenou pracovní dobu. Údaje získané metodou dotazníkového šetření byly zjišt’ovány na základě dobrovolné účasti uchazečů o zaměstnání v rámci uvedeného výzkumu. Kritériem klasifikace dat byla uvedená výše podpory $\mathrm{v}$ nezaměstnanosti. $\mathrm{Z}$ celkového počtu oslovených respondentů pobíralo $\mathrm{v}$ době realizace výzkumu $39 \%$ uchazečů o zaměstnání podporu v nezaměstnanosti v rozpětí od 4001 Kč do $8000 \mathrm{Kč}$. Z celkového počtu oslovených respondentů se $\mathrm{k}$ výši podpory v nezaměstnanosti nevyjádřilo $9 \% \mathrm{z}$ nich. Průměrná výše podpory v nezaměstnanosti $\mathrm{v}$ době realizace výzkumu v roce 2010 byla 5698 Kč (Analýza vývoje zaměstnanosti a nezaměstnanosti v roce 2010. MPSV ČR). Výsledky statistického šetření jsou uvedeny v tabulce č. 4. Velmi zajímavým zjištěním se jeví 86 \% kladných vyjádření k možnostem práce na zkrácenou pracovní dobu v kategorii uvedeného rozpětí vyplacených podpor v nezaměstnanosti od 4001 Kč do 8000 Kč a 43 \% souhlasných vyjádření v kategorii 0 Kč až 4000 Kč. Uvedené výsledky podtrhují nesouhlasná poměrová vyjádření $\mathrm{k}$ možnostem práce na zkrácenou pracovní dobu v rozpětí vyplacených podpor v nezaměstnanosti od $8001 \mathrm{Kč} \mathrm{do} 12000 \mathrm{Kč}$ a to $60 \%$ a v rozpětí od 12001 Kč a výše dokonce 67 \%. Systematickou analýzou dat jsem došla k závěru, že na rozhodování o možnosti pracovat i když na zkrácený pracovní úvazek má vliv výše podpory v nezaměstnanosti pobíraná v současnosti uchazečem o zaměstnání. Pro uchazeče, kteří pobírali podporu v nezaměstnanosti vyšší než 8000 Kč, není práce na zkrácenou pracovní dobu přijatelná. Práci na kratší pracovní úvazek by využili právě ti uchazeči, jejichž výše podpory v nezaměstnanosti se pohybovala v rozpětí od $4001 \mathrm{Kč} \mathrm{do} 8000 \mathrm{Kč}$. Na základě výsledků šetření se proto domnívám, že výše podpor v nezaměstnanosti jako alternativní zdroj př́ijmu je pro mnohé uchazeče dostačující ne-li vyhovující a nepůsobí motivačně pro hledání nového pracovního místa.

Tabulka č. 4: Preference práce na zkrácenou pracovní dobu

\begin{tabular}{|c|c|c|c|c|}
\hline Výše podpory & Ukazatel & \multicolumn{3}{|c|}{ Preference práce na ZPD v \% } \\
\cline { 3 - 5 } v nezaměstnanosti v Kč & struktury v \% & Ano & Ne & Neuvedeno \\
\hline $0-4000$ & 18 & 43 & 28 & 29 \\
\hline $4001-8000$ & 39 & 86 & 14 & 0 \\
\hline $8001-12000$ & 26 & 40 & 60 & 0 \\
\hline $12001-$ více & 8 & 33 & 67 & 0 \\
\hline neuvedeno & 9 & 67 & 33 & 0 \\
\hline
\end{tabular}

Zdroj: dotaznikové šetrení v rekvalifikačnich kurzech 


\section{Využití flexibilních forem zaměstnávání v podmínkách pracovního trhu ČR}

Trh práce v ČR se nevyvíjel ve sledovaném období let 2008 až 2010 z makroekonomického hlediska příznivě. Nerovnováha trhu práce vyjádřená ukazatelem míry nezaměstnanosti podle nové metodiky MPSV ČR se zvýšila z $6 \%$ na konci roku 2008 na 9,6 \% v roce 2010. Podle Analýzy vývoje zaměstnanosti a nezaměstnanosti v roce 2010, vydané MPSV ČR, jsou predikce vývoje ekonomiky v České republice pro rok 2011 ne zcela optimistické, což se projeví také na trhu práce. $\mathrm{Na}$ trhu práce v České republice začíná docházet také $\mathrm{k}$ nerovnováze $\mathrm{v}$ kvalifikační struktuře nabídky práce tvořené domácnostmi a poptávky po práci zaměstnavatelů. Poptávka po práci se projevuje zvýšenou potřebou vysoce kvalifikovaných pracovníků, zaměstnavatelé problematicky obsazují některá pracovní místa a nemohou na nabízenou pracovní pozici najít vhodného pracovníka $\mathrm{s}$ požadovanými kvalifikačními předpoklady. $\mathrm{Na}$ druhé straně pracovního trhu dochází k výraznému počtu nezaměstnaných osob, které se nemohou uplatnit na trhu práce. Jedná se zejména o osoby dlouhodobě nezaměstnané, o matky pečující o děti a o absolventy škol. Právě pro výše uvedené skupiny nezaměstnaných by mohlo být využívání flexibilních forem zaměstnávání velmi vhodné. V zemích Evropské unie, které využívají práci na zkrácenou pracovní dobu, o nichž se zmiňuji ve druhé kapitole článku, mají nejen nízkou průměrnou míru nezaměstnanosti, ale také nízkou míru nezaměstnanosti mladých osob do 25 let. Průměrná míra nezaměstnanosti mladých do 25 let je za rok 2010 v Evropské unii na úrovni 20,9\%, v Nizozemí 8,7 \% a v Rakousku 8,8 \%. Nezaměstnanost mladých je v České republice na úrovni $18,4 \%$. (Analýza vývoje zaměstnanosti a nezaměstnanosti v roce 2010. MPSV ČR).

Myslím si, že pokud by byli zaměstnavatelé více motivováni k vytváření nových pracovních míst pro výše uvedené skupiny nezaměstnaných při využívání zkrácených pracovních úvazků, situace na trhu práce by se mohla vyvíjet př́znivěji nejen pro nezaměstnané, ale pro celou společnost $\mathrm{s}$ ohledem na snižování rozpočtových výdajů na podpory v nezaměstnanosti. Podle mého názoru by mohlo docházet také $\mathrm{k}$ větší pravděpodobnosti obsazování již zmíněných vysoce kvalifikovaných pracovních míst, nebot' věřím, že mezi absolventy škol i ostatními uvedenými skupinami nezaměstnaných jsou kvalitní a kvalifikované zdroje pracovních sil, které možná jen čekají na př́ležitost, aby v sobě objevily schopnosti, na které trh práce čeká.

\section{Závěr}

Trh práce v České republice a v celé Evropské unii byl ve sledovaném období let 2008 až 2010 specifický růstem míry nezaměstnanosti, která je projevem tržní nerovnováhy způsobené nesouladem nabídky práce a poptávky po práci. V uvedeném období jsem sledovala podíl zaměstnaných na zkrácenou pracovní dobu ve vybraných zemích Evropské unie a v České republice. Země, které využívají flexibilní formy zaměstnávání ve větším rozsahu, vykazují ve sledovaném období nižší míru nezaměstnanosti než země ostatní. Nejvíce je výše uvedená forma zaměstnávání využivána v Nizozemí, v Dánsku, v Německu a v Rakousku. V České republice pracuje na zkrácený pracovní úvazek pouze 5,9\% zaměstnaných, což je v komparaci s průměrem v Evropské unii výrazně nízké číslo. Příčinou uvedeného stavu je nízká úroveň prríjmů zaměstnaných na kratší pracovní dobu a nedostatečná nabídka pracovních pozic zaměstnavatelů.

Ve sledovaném období se podíl zaměstnaných na zkrácenou pracovní dobu zvýšil z 245,3 tisíc v roce 2008 na 288,6 tisíc zaměstnaných v roce 2010 . Počet podzaměstnaných osob však vzrostl z 37,9 tisíc osob v roce 2008 na 60,4 osob v roce 2010. Tito zaměstnaní pracují v hlavním zaměstnání na částečný úvazek, přsstože by rádi pracovali na úvazek plný. Na trhu práce v České republice se projevuje negativní flexibilita nedobrovolnou podzaměstnaností, 
jejímž důsledkem je existence pracovní nejistoty provázena nízkým platovým ohodnocením. Na základě výsledků v rámci výzkumu o zaměstnávání na zkrácený pracovní úvazek mezi uchazeči o zaměstnání jsem zjistila, že v průměrném vyjádření by upřednostnilo práci na částečný pracovní úvazek až 50 \% dotazovaných respondentů, převážně žen, jejichž současná výše podpory v nezaměstnanosti nepřevyšuje částku 8000 Kč.

Flexibilní formy zaměstnávání jsou vhodné pro určité skupiny osob, zejména pro absolventy škol, ženy pečující o děti a dlouhodobě nezaměstnané, za předpokladu udržení pozitivní stránky flexibility pracovního trhu projevující se sladěním soukromého života s prací. Pro výše uvedené kategorie nezaměstnaných by mohla být tato forma zaměstnávání novým vstupem na trh práce. Myslím si, že pokud by byli zaměstnavatelé motivováni k vytváření nových pracovních pozic při využívání flexibilních forem zaměstnávání, trh práce by se vyvíjel příznivěji pro všechny zúčastněné subjekty.

\section{Literatura:}

[1] ARMSTRONG, M. Řizení lidských zdrojů. 1. vyd. Praha: Grada Publishing, 2007, 800 s. ISBN: 978-80-247-1407-3.

[2] BIERZOVÁ, J., DUDOVÁ, R. Nové šance a rizika: Flexibilita práce, marginalizace a soukromý život u vybraných povolání a sociálních skupin. 1. vyd. Praha: Sociologický ústav Akademie věd ČR, v.v.i., 2008, 308 s. ISBN: 978-80-7330-138-5.

[3] BROŽOVÁ, D. Společenské souvislosti trhu práce. 1. vyd. Praha: Sociologické nakladatelství, 2003, 185 s. ISBN 80-86429-16-4.

[4] HENDL, J. Kvalitativní výzkum: základní teorie, metody a aplikace. 2. vyd. Praha: Portál, s.r.o., 2008, 408 s. ISBN: 978-80-7367-485-4.

[5] KOCIANOVÁ, R. Personální činnosti a metody personální práce. 1. vyd. Praha: Grada Publishing, 2010, 224 s. ISBN:978-80-247-2497-3.

[6] SAMUELSON, P. A., NORDHAUS W. D. Ekonomie. 1. vyd. Praha: Nakladatelství Svoboda, 1991, 1011 s. ISBN: 80-205-0192-4.

[7] Analýza vývoje zaměstnanosti a nezaměstnanosti vroce 2008. MPSV ČR, č.j. 2009/28873-14. Dostupná z WWW: www.portal.mpsv.cz/sz/politika zaměstnanosti.

[8] Analýza vývoje zaměstnanosti a nezaměstnanosti v roce 2009. MPSV ČR, č.j. 2010/31863-163. Dostupná z WWW: www.portal.mpsv.cz/sz/politika zaměstnanosti.

[9] Analýza vývoje zaměstnanosti a nezaměstnanosti vroce 2010. MPSV ČR, č.j. 2011/32897-411. Dostupná z WWW: www.portal.mpsv.cz/sz/politika zaměstnanosti.

\section{Klasifikace JEL: E24}

\section{Ing. Ivana Brožíková}

Učitelka odborných předmětů

Obchodní akademie, Orlová, prŕíspěvková organizace

Polní 964, 73514 Orlová - Lutyně

brozikova@obaka-orlova.cz 